\title{
Alternatives for Dumpsite Scavenging: The Case of Waste Pickers at Lusaka's Chunga Landfill
}

\author{
B. Chileshe, M.S. Moonga* \\ *Lecturers in the Department of Language and Social Sciences Education, School of Education, \\ University of Zambia, Lusaka, Zambia
}

\begin{abstract}
The extreme poverty levels being experienced in Zambia are driving some people in urban areas to venture into informal menial jobs such as street vending, stone crushing and street car cleaning. These jobs have provided some respite from poverty for many of the lowly educated who cannot get decent jobs in the formal sector. The jobs have been a source of livelihood for many households, especially in the peri-urban areas of the cities. One such job is waste picking, an activity conducted at the country's landfills and dumpsites. Literature shows that waste picking has both advantages and disadvantages. On one hand, it contributes enormously to informal sector job creation and therefore gives people a livelihood. It might also be the only available method of waste management in some countries. On the other hand, waste picking exposes those who practice it to many hardships as well as health and occupational risks and hazards. This study investigated waste picking at Chunga Landfill in Lusaka, the capital city of Zambia. A questionnaire was used to elicit information from 22 waste pickers and five city council officials about the socio-economic benefits and costs of waste picking at the landfill. The study established that, consistent with earlier research findings, waste pickers at Chunga Landfill underwent a lot of hardships and suffered many socio-economic costs. The study recommends sustainable job alternatives which provide people with livelihoods but also give them the dignity that human beings deserve.
\end{abstract}

Keywords: Landfill; waste pickers; socio-economic benefits, socio-economic costs, sustainable alternatives; occupational hazards; environmental risks.

\section{BACKGROUND}

Lack of employment and high poverty levels in Zambian cities have driven some residents to the limit. In the absence of formal employment, residents have resorted to different ways of earning a livelihood in the informal sector. In the peri-urban areas, people have turned to charcoal burning and growing vegetables which they can sell within the precinct of the urban areas to earn an income. Within the inner city, residents engage themselves in activities such as street vending, stone crushing, and doing other odd jobs in their quest for survival. One interesting occupation which has, however, gone on almost unnoticed is that of scavenging on rubbish dumps. Whole families live and subsist on garbage which is dumped in various parts of the cities. The largest of these is Chunga Landfill (Figures 1 and 2), which is the official garbage disposal site for the Lusaka City Council (LCC). The landfill is located on the northern side of the City of Lusaka, near the boundary with Chisamba (a district in Central Province). The dumpsite was constructed in the year 2006 funded by the Danish Government. The Landfill was initially meant to run as a well-engineered commercial landfill but, over the years, lack of funding and improper management have led to deterioration of conditions at the dumpsite. Since its construction, the dumpsite has accommodated garbage from every part of the city. The garbage, which is mostly unsorted, includes plastics, paper, bottles, kitchen waste, clinical waste, commercial waste and industrial waste. This waste has attracted a horde of scavengers (who will be referred to as waste pickers in this paper) who rummage through it to pick what they consider to be of value. This includes food items, bottles, plastic bags and other items which they either use themselves or resale to unsuspecting members of the general public. 


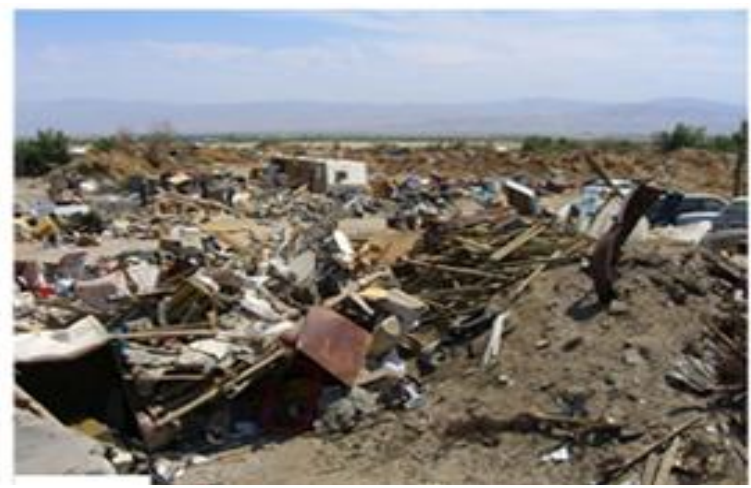

Figure1. Chunga Landfill

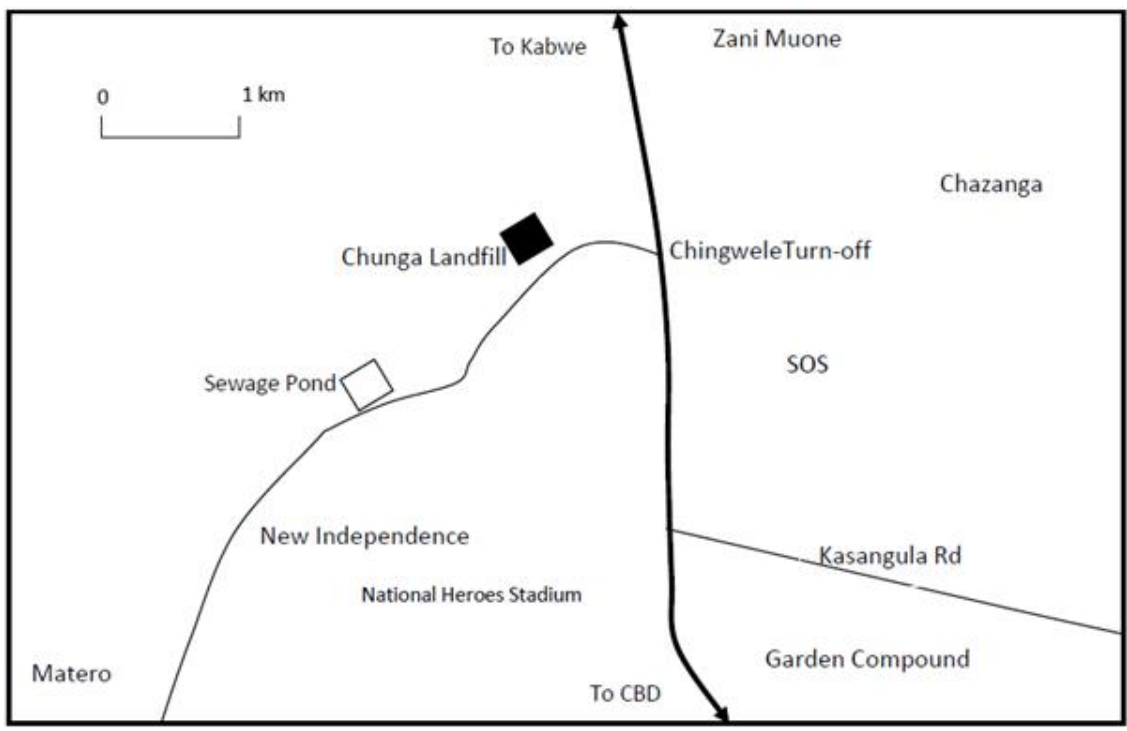

Figure2. Location of Chunga Landfill in Lusaka

\section{Statement of the Problem}

Waste picking constitutes an environmental hazard in that the items that are picked from the dumpsite are consumed by the waste pickers themselves or sold to unsuspecting people away from the Landfill. This poses a health risk to both the waste pickers and to the people who buy items from them. It was, therefore, imperative to establish the alternatives that could be provided to the waste pickers so that they could stop depending on the Landfill for subsistence.

\section{Aim}

The aim of this study was to investigate alternatives for scavenging or waste picking as a source of livelihood by waste pickers at Chunga Landfill in Lusaka.

\section{Objectives}

The objectives of the study were to:

(a) ascertain the socio-economic benefits that accrue to the waste pickers.

(b) investigate health implications of waste picking at Chunga Landfill.

(c) determine alternatives for waste pickers that can help them to change to other ways of living.

\section{Research Questions}

The following questions guided this study:

(a) What socio-economic benefits do waste pickers derive from waste picking?

(b) What health implications are there for the waste pickers and the people who buy their merchandise?

(c) How can the waste pickers be helped to get out of waste picking to other ways of life? 


\section{Rationale}

This study was important because it addressed a problem which hitherto had not been given a lot of attention in Zambia. It was to bring to the fore the plight of a people who wanted to make it in life but whose only hope for then was to forage through waste in order to live. The findings of this study would be useful to planners in both local and national government; they could also be used by NGOs and FBOs whose interest was to help the vulnerable in the community. The study would also add to the scanty literature available on the social aspects of environmental issues in Zambia. There was need to document these issues for the sake of academia as well as enabling policy makers make informed decisions.

\section{LITERATURE REVIEW}

Srinivas (n.d) defined a scavenger or waste picker as a person who salvages reusable or recyclable materials thrown away by others to sell or for personal consumption. In this case, the waste picker's work place is a landfill or a dumpsite which is a site for the disposal of wastes by burial (Figure 3).Available literature indicates that waste picking is a worldwide phenomenon(Gowan, 1997) which dates back to ancient times (Medina, 2007). In 1988, the World Bank estimated that $1-2 \%$ of the world population lived by waste picking (Bartone, 1988). Waste pickers have been described as vital contributors to the social, ecological and economic sectors of the cities in which they operate. According to Scheinberg and Anschütz (2007, they may provide the only waste collection service in some cities.

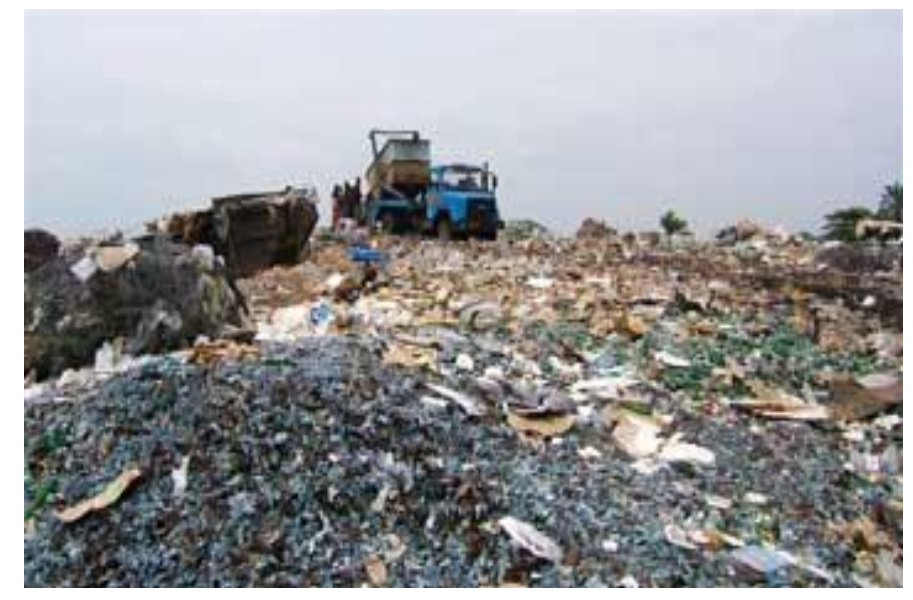

Figure3. A garbage dumpsite - the working environment for waste pickers

Several causes have been advanced for waste picking in both developing and developed countries. Wilson, Velis, and Cheeseman (2005) attributed rapid expansion of waste picking in developing countries to two factors: urbanisation and lack of formal sector employment. Facilitation by urbanisation has been through the creation of a large pool of unemployed and underemployed residents with few alternative means of earning a livelihood. New arrivals from rural areas and those who lack formal education may not get jobs in the formal sector. This results in unemployment, defined by the World Bank (2014) as the share of the labour force that is without work but available for and seeking employment. Lack of formal employment in urban areas results in extreme poverty among many urban dwellers. According to the CIA, the world unemployment rate was $8.4 \%$ in 2011 and rose to $9 \%$ in 2012. These seemingly low figures were, however, for the entire world; in 2007, unemployment and underemployment was at $30 \%$ in many developing countries and was only $4-12 \%$ in developed countries (CIA, 2013).In 2005, unemployment rate in Zambia stood at 16\% (Zambia CSO); in 2006, the World Bank indicated that $59.3 \%$ of Zambians lived below the poverty datum line (World Databank) while the CIA indicated 64\% for the same year (CIA World Factbook). In 2010, the United Nations ranked Zambia 150 out of 169 countries on the Human Development Index. The country, therefore, remains one of the least developed countries in the world.

With these escalating and rampant levels of poverty in developing countries, waste picking contributes immensely to informal sector job creation and economies generally (Medina, 2007). Studies indicate that recycling activities by this sector can generate significant employment, especially for women. For example, Iskandar (2001) reported that 7-8 jobs per ton of waste are provided daily in Cairo. 


\section{B. Chileshe \& M.S. Moonga}

In developed countries, two factors contributed to the informal recycling boom which started in the mid-1990s (Gowan, 2010). The first factor was the surge in demand for informal recycling as a result of increase in waste production, declining space in landfills, new recycling technologies and the push by environmentalists. The second factor was change in the political economy of the industrialised countries. Gowan (1997) explained that, during the mid-1990s, there were losses of manufacturing jobs, cutbacks to government employment and a roll back of the welfare state. These events led to an increase in the number of the poor, working poor, and homeless.

In addition, many municipal councils cannot cope up with the collection and disposal of the huge amounts of garbage that continue to be generated within their city perimeters. This is the scenario in Lusaka where Chaampa's (2013) study revealed that some areas of the city were becoming infested with solid wastes because the city council could only collect ten percent of all the garbage generated. Therefore, the various diversions of waste, including small-scale recycling activities done by waste pickers, can significantly reduce the mass of waste that requires more centralised solutions (Bogner, 2007). In Cairo (Egypt), waste pickers can recycle up to more than $50 \%$ of collected waste (Iskandar, 2001). A study conducted by the GTZ/CWG in 2007 found that waste pickers recovered approximately $20 \%$ of all waste material in the six cities studied (GTZ, 2010).

Clearly, waste picking provides a source of livelihood to extremely poor people who have few or no alternatives for formal employment. However, in spite of the numerous socio-economic benefits that accrue to waste pickers and the cities they operate in, waste pickers world over face many hardships and lack access to social mobility (Parizeau, 2013). These hardships include stigma, exploitation by middlemen (where middlemen exist), and hazardous/precarious working and living conditions. Waste pickers are exposed to many kinds of health risks, including unsanitary conditions (skin irritations, vitamin deficiencies, tuberculosis and tapeworm) and violence. They are also exposed to pungent odours, insect bites and diseases that are transmitted by rodents, cockroaches, and flies. In Java, Dadi, a 25-year old new waste picker, explains that adjusting to the life of a waste picker can be difficult, that for weeks after arriving at the landfill where she worked, she could not eat properly and vomited every day because of the offensive odour. In 2013, the then spokesperson at Zambia's Environmental Management Agency (ZEMA), Ms. Chipili, described conditions at Chunga Landfill as poor and would lead to outbreaks of diseases such as cholera and dysentery. If this happened, according to her, it would be a big cost to government (Lusaka Times, August 1, 2013). This is the work place for waste pickers who scavenged for items which they later sold to members of the general public. Bogner (2007) asserts that the challenge for the future is to provide safer, healthier working conditions for waste pickers than they currently experience on uncontrolled dumpsites. Iskandar (2001) is of the view that women can be helped through creative microfinance and other small-scale investments which can help them to get started elsewhere or to get working tools such protective clothing.

\section{Methodology}

The study used a qualitative and descriptive survey research design which was aimed at eliciting and describing opinions and attitudes of waste pickers at Chunga Landfill and those of officers at the Environmental Health Department of the Lusaka City Council. The information was collected using interviews and document study.

The sample consisted of all the waste pickers at the landfill who were present on the day of the interviews and all the members of the Environmental Health Department at the Lusaka City Council. Using this sampling frame, 22 waste pickers and five members of the Environmental Health Department at the Council were interviewed. Expert purposive sampling was used to select officials from the Lusaka City Council's Health Department. Purposive sampling was also used to select waste pickers at Chunga Landfill because only waste pickers at Chunga Landfill met the purpose of the study.

The information collected was analysed using frequencies and percentages and the data were presented in tables and graphs.

\section{FINDINGS AND DISCUSSION}

This section presents and discusses the results of the study which include the demographics of the respondents, socio-economic benefits of waste picking at Chunga Landfill, socio-economic costs of waste picking at the landfill, occupational hazards and environmental risks of waste picking at the landfill and the need to find alternative activities for the waste pickers. 


\section{Demographics of the Respondents}

Following Rudestam and Newton (2001 cited in Mulenga, 2015: 108), the presentation of findings begins with a description of the demographic details of the sample from which the data was collected (Table 1).

Table1. Demographic Characteristics of the Sample

\begin{tabular}{|l|c|c|c|}
\hline Variable & Category & $\begin{array}{c}\text { Frequency } \\
\mathbf{n = 2 2}\end{array}$ & Percentage \\
\hline 1. Gender & Male & 10 & 45 \\
2. Age (years) & Female & 12 & 55 \\
& $10-20$ & 9 & 41 \\
& $21-30$ & 3 & 14 \\
& $31-40$ & 2 & 9 \\
& $41-50$ & 4 & 18 \\
& $51-60$ & 3 & 14 \\
3. Level of education & $>61$ & 1 & 4 \\
& No formal & 4 & 64 \\
& Primary & 14 & 18 \\
4. Economic age group & Secondary & 4 & 0 \\
& Tertiary & 0 & 0 \\
& Young dependent & 0 & 86 \\
& (<15 years) & & 14 \\
\hline & Economically active & 19 & \\
\hline
\end{tabular}

The results for demographic characteristics show that, by the gender of the waste pickers, more women $(55 \%)$ were involved in waste picking at Chunga Landfill than men. The results for age show that $41 \%$ of the waste pickers were young adults who should still have been at school or college. As for educational attainment, the results show that the majority of waste pickers at the Landfill only went up to primary school. The results also show a bundling of the waste pickers around the economically active age group (15 - 55 years). The implications of these results are discussed under the socio-economic costs of waste picking at Chunga Landfill.

\section{Socio-Economic Benefits of Waste Picking at Chunga Landfill}

The first objective of this study was to establish the socio-economic benefits for engaging in waste picking at Chunga Landfill. Responses elicited from the waste pickers at the Landfill and officials from Lusaka City Council are shown in Figures 4 (a) and (b), respectively.

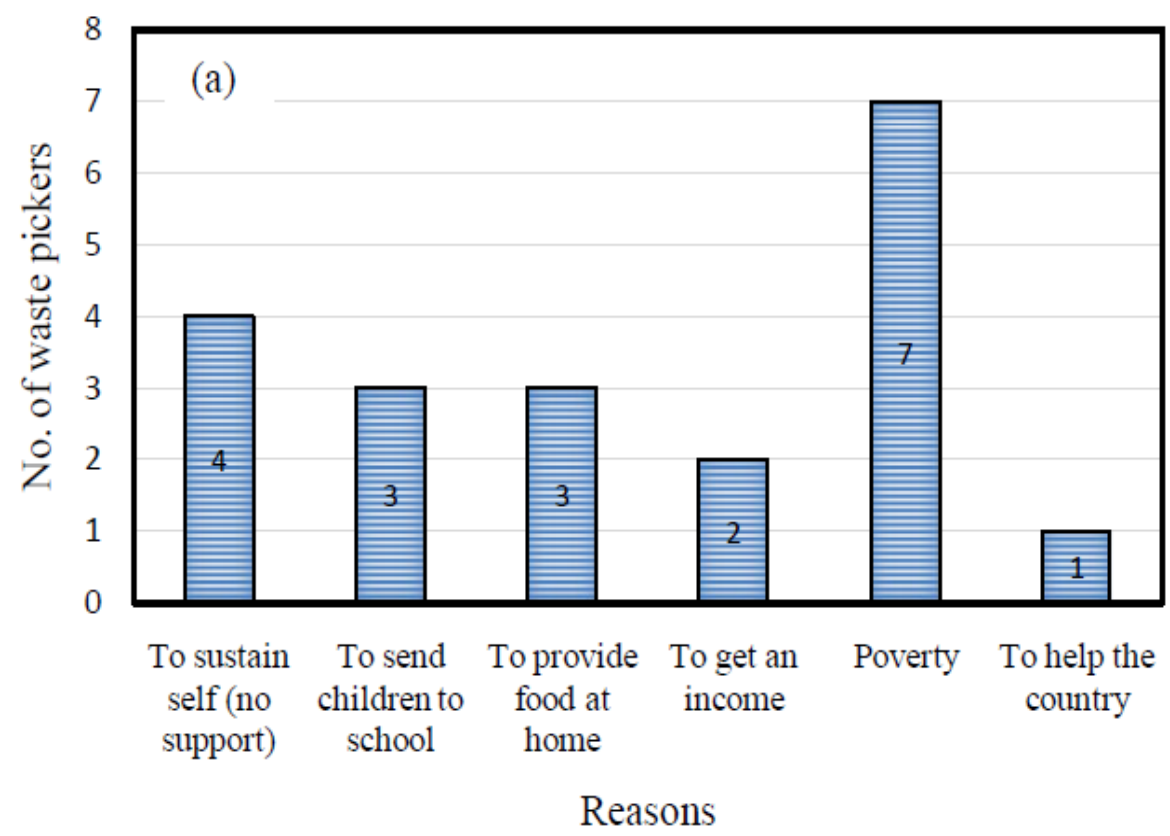




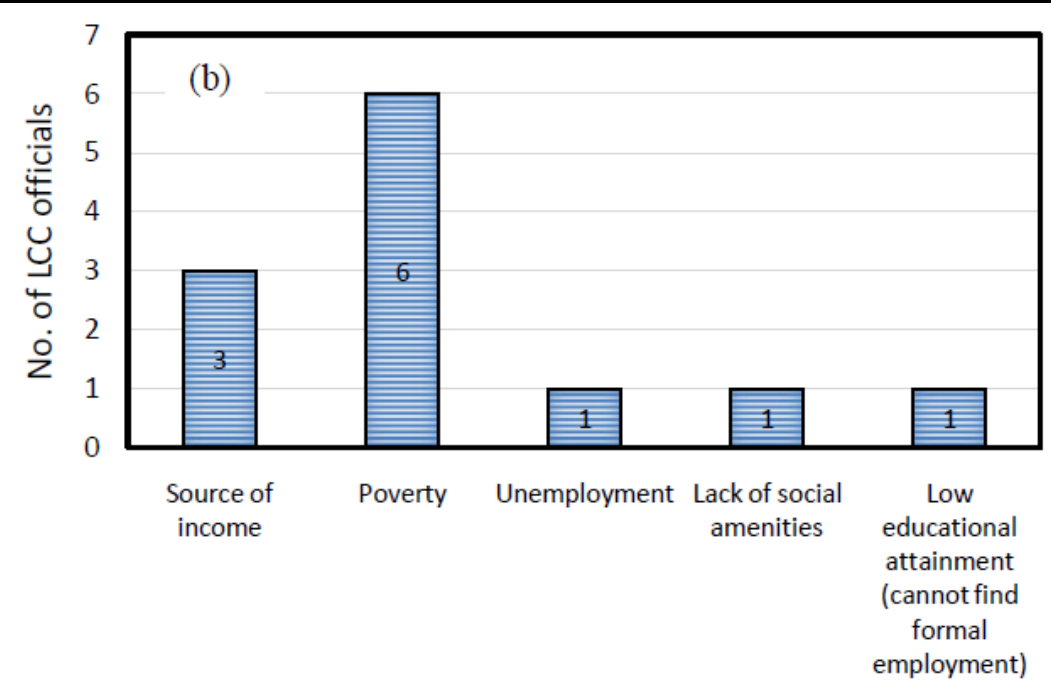

Reasons

Figure4. Reasons for engaging in waste picking

Note that for graph (b), the respondents were allowed to give multiple responses.

The data from the two graphs above show that poverty was cited as the major reason for engaging in waste picking by both the waste pickers themselves and the council officials. It can, therefore, be said that waste picking was an escape route out of poverty for many of the waste pickers. This is consistent with Medina's (2007) assertion that waste picking provides a source of livelihood to extremely poor people with few other employment prospects. For younger people who did not have adult support or for widowed women, waste picking could also be a way for self-support.

Earning an income was another important reason why people engaged in waste picking at Chunga Landfill. Figure 5 shows that $90.5 \%(n=19)$ of the waste pickers reported selling the items that they salvaged from the landfill. This means that the vendors themselves hardly consumed the proceeds of waste picking.

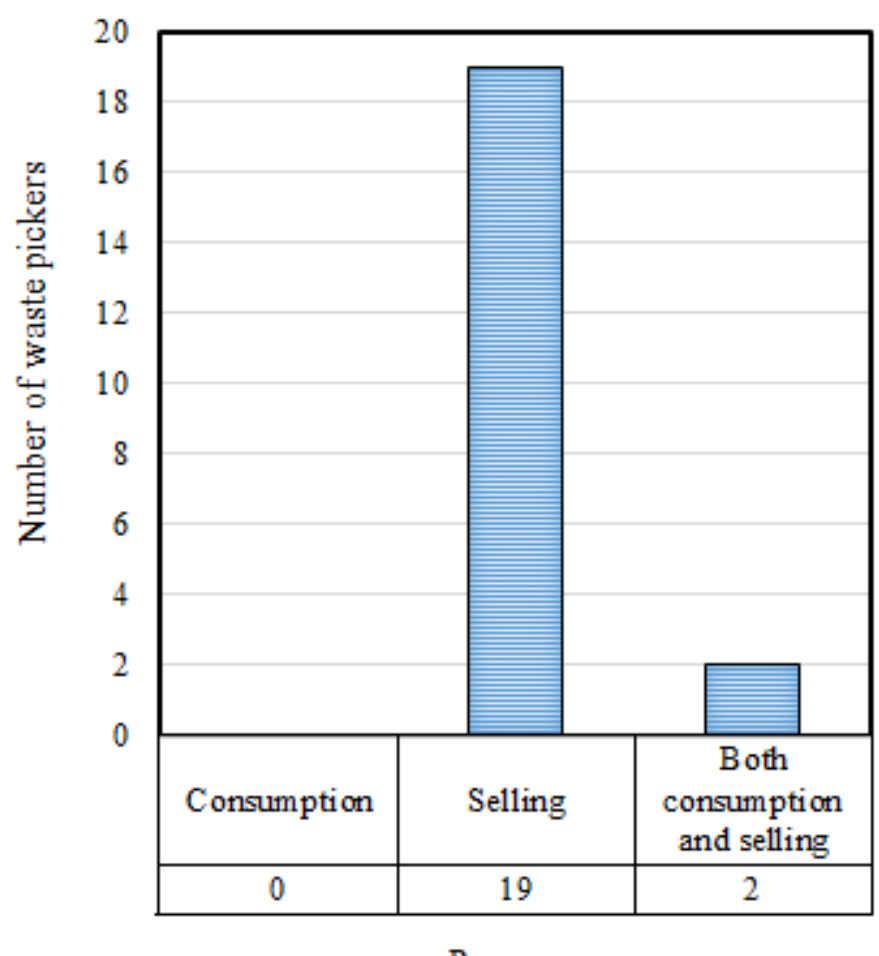

Purpose

Figure5. Disposure of proceeds from waste picking

The respondents reported that money obtained from selling landfill products was used for the purposes shown in Table 2 below: 
Table2. How waste pickers spent money earned from selling landfill products

\begin{tabular}{|l|}
\hline (a) Buying school requisites and paying school fees for children \\
\hline (b) Buying food \\
\hline (c) Construction of houses \\
\hline (d) Paying rentals \\
\hline (e) Buying clothes
\end{tabular}

The table shows that money earned from selling waste picking products went to meeting the waste pickers' basic needs for shelter, clothing and food as well as sending children to school. All these activities were important in the lives of waste pickers. In fact, paying for school for children was imperative if the vicious cycle of poverty within their families was to be curtailed. The study shows that using money on basic needs was the most important reason for engaging in waste picking further corroborating the assertion that the poor spend more time looking for means of survival than on minding about other equally important aspects of life such as cleanliness and hygiene (Mweemba, in press).

\section{Socio-Economic Costs of Waste Picking at Chunga Landfill}

The second objective of this study was to investigate the socio-economic costs of waste picking at Chunga Landfill. The parameters used to determine the costs were gender and age since women, children, and the elderly are known to be among the most vulnerable members of society (WHO, 2005). Other parameters were educational attainment and economic cohorts.

Gender

Information by gender of the waste pickers shows that more women were involved in waste picking than men at Chunga Landfill. This is consistent with the claim by Women in Informal Employment: Globalizing and Organizing (WIEGO, 2014) that a significant number of waste pickers in the world were women. The significance of this finding to this study is that women have more pressure than men to provide for their families and to ensure that children went to school. Huysman (1994), writing about female waste pickers in India, explains that, despite the low returns and the health risks, waste picking offers one of the few ways in which women from lower castes can earn an income and also meet their household and child-rearing responsibilities. Therefore, women's entry into waste picking can be seen to be largely a poverty mediation measure which Parizeau (2013) justly calls a household level economic coping strategy. The problem, however, is that these women also have to play several other roles in the household. Apart from earning an income and saving on expenditure, they also have to care for members of the family and do domestic chores. These other roles may suffer as the women spend more time picking waste from the dumpsites.

Age

The results show that $41 \%$ of the waste pickers by age were young adults who should still have been at school or college. This is a problem because, as ILO/IPEC (2004) puts it, waste picking interferes with the education of children and young adults as it takes them away from school. With lack of education, these young people may not be able to find better paying jobs in the formal sector as adults, therefore perpetuating the problem of extreme poverty in their families (CIA, 2013). ILO/IPEC also asserts that waste picking harms the young people's physical, emotional and social well-being, as they are exposed to stigma and physical injury.

\section{Educational attainment}

Table 1 shows that the majority of waste pickers (64\%) at Chunga Landfill only went up to primary school. Significantly, this implies that these waste pickers came from the section of society of the uneducated. To this effect, WIEGO (2014) asserts that waste picking is easily learned and usually does not require literacy. Similarly, Parizeau (2013) states that waste picking allows those with little education or formal training to enter the labour market. However, waste picking is a marginalized form of employment and those who engage in it, like sanitary workers, are looked at and treated with disdain and disparagement (Vidanaarachchi et al., 2006). Douglas, (1984) reports that, in India where there is a caste system, 'dirty jobs', such as waste management, cleaning toilets or washing clothes, belong to the lower caste people. This is how waste pickers are looked upon everywhere in the world.

Economic cohorts

The results show a bundling of the waste pickers around the economically active age group (15- 55 years). The implication of this finding is that most of the waste pickers should have been in more 
gainful formal or non-formal employment and contributing substantially to the economy of the country. Instead, these people spend a lifetime rummaging through waste. Parizeau (2013) succinctly explains that this group of people do not have to pay income tax on their earnings. This is certainly a drawback on the economy of the country.

\section{Occupational Hazards of Waste Picking at Chunga Landfill}

Apart from socio-economic problems, waste pickers at Chunga Landfill also face many environmental and occupational risks. According to Binion and Gutberlet (2012), there is a high prevalence of infectious disease among waste pickers due to their exposure to hazardous materials, such as fecal matter, paper saturated by toxic materials, bottles and containers with chemical residues, contaminated needles, and heavy metals from batteries. The results of this study show that waste pickers at Chunga Landfill reported that they were likely to suffer from health risks shown in Table 3 below.

Table3. Health risks that waste pickers at Chunga Landfill were exposed to

(a) Communicable diseases resulting from coming into contact with discarded dead animals and medical waste.

(b) Diarrheal diseases resulting from ingesting contaminated foodstuffs from the dumpsite.

(c) Skin diseases resulting from coming into contact with dirt.

(d) Respiratory diseases such as TB resulting from inhalation of dust and smoke.

(e) Accidents and physical injuries resulting from fires, sharp objects, trucks.

(f) Choking or suffocation resulting from incessant smoke at the landfill. Sharp objects may result into physical injury.

Forty-five percent of the waste pickers indicated that they had actually suffered from health-related problems shown in Table 3 while 55\% said they had not. Figure 6 shows the health problems actually suffered by waste pickers at Chunga Landfill.

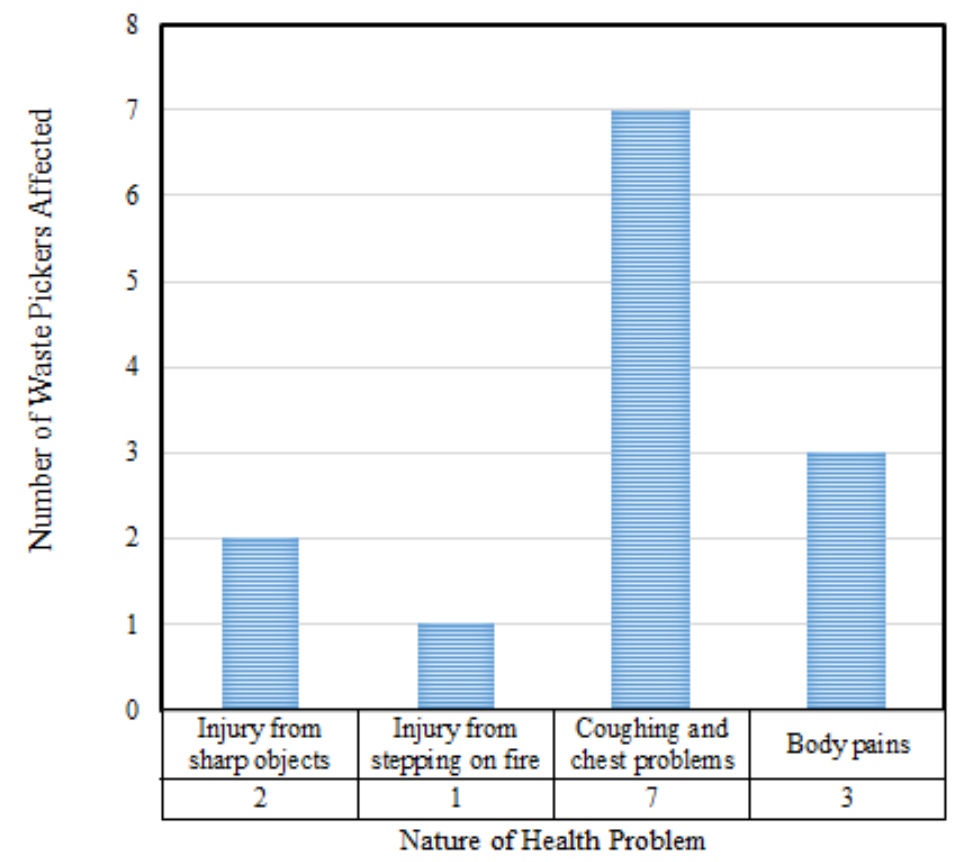

Figure6. Nature of health problems suffered as a result of waste picking at Chunga Landfill

(Note: The respondents were allowed to give multiple answers)

The results show that coughing and chest problems resulting from smoke and dust at the Landfill was the most prevalent complaint among waste pickers, followed by body pains emanating from working for long hours and lifting heavy objects. These findings resonate with those of Gutberlet (1997) who noted that among the most common types of job-related injuries for waste pickers are back and hand injuries caused by lifting heavy objects with little equipment. In his study of 48 waste pickers in Santo André, Brazil, Gutberlet found that almost all workers reported pain in the back, legs, shoulders, arms, and hands. Injury from stepping on or mishandling sharp objects, such as broken bottles and pieces of metal, was the third most reported problem. 


\section{Environmental Risks Associated with Waste Picking at Chunga Landfill}

The Environmental Health Department of Lusaka City Council also reported environmental problems related to waste picking at Chunga Landfill (Table 4).

Table1. Environmental problems resulting from picking waste at Chunga Landfill

(a) Waste pickers scatter waste which attracts rodents, vermin and pests. These are vectors which carry a myriad number of diseases.

(b) Scattered waste also causes water pollution (both surface and underground) because the waste cannot be not properly managed. It cannot be landfilled, compacted and covered with earth.

(c) Waste which is not landfilled becomes an eyesore (visual pollution), causes bad smell and fly nuisance.

(d) Waste pickers start unwanted fires. This leads to the presence of heavy smoke at the landfill which chokes people working and living around the landfill.

(e) Waste pickers disturb the normal operation of the landfill. They jump onto moving waste trucks, scattering and littering waste around the Landfill and running a danger of being overrun by the trucks.

(f) Waste pickers take back into communities discarded rubbish.

\section{Need for Sustainable Alternatives for Waste Pickers}

The indications from the above findings are that scavenging or waste picking at the Chunga Landfill is a socio-economic as well as an environmental problem. Lack of jobs and, therefore, lack of incomes is the major driving force for engaging in waste picking at the Landfill. The socio-economic environment is about people's access to jobs in their areas and having money to spend on their basic needs(O’Donoghue \&van Rensburg, 1995;SADC REEP, 2002).However, almost all waste pickers working at the Landfill were people without (enough) formal education and could, therefore, not find viable formal employment. It is argued, therefore, that unless practical and economically sustainable alternatives were made available to them, it was difficult to discourage these people from engaging in waste picking.

In discussing the issue of helping the waste pickers to change from scavenging to other ways of earning a livelihood, two levels could be considered. The first level involves changing the mindset, perceptions and attitudes of the waste pickers themselves. This entails that they should understand the imperatives of changing from waste picking to more viable occupations such as collecting and sorting waste, or getting into semiformal employment. According to Steiner and Rihoy (1995), engaging the waste pickers as waste sorters and recoverers is a helpful alternative because it works along the principles of community-based natural resource management (CBRM), an initiative in which communities also receive economic benefits from their actions, and is more respectable. The benefits accruing from the alternatives must, however, exceed the perceived costs of engaging in them and must be secure over time.

The difficult is that the mindsets and attitudes among waste pickers are completely different. One feeling among them is that their 'occupation' makes them their own bosses. As a result, they would not want to be employed by 'another boss'. Some think their lives belong to the landfill, as shown by Umi, a 47-year-old former Indonesian paddy farmer who transitioned to living on a dumpsite called Bantar Gebang. She stated that she went to live at the dumpsite because the work was good and she could be her own boss. She thought money was faster than growing rice and the work was lighter (guardian.co.uk). Similarly, Nila, a waste picker in Jakarta, stated that her life belonged to the waste dump where she met her partner and where her life was. Additionally, waste pickers may feel that their occupation affords flexibility in terms of schedules, working locations and ability to attend to other responsibilities while working (such as child care, household errands, etc.), an aspect cited as a benefit by some survey respondents investigated by Parizeau (2013).

These are some of the notions which need to be changed if waste pickers are to be helped to transform to more viable occupations. The waste pickers at the Chunga Landfill were not asked to state why they did not want to stop waste picking but 59\% of them did say they preferred to stay on.

The methods used by the Lusaka City Council to remove waste pickers from the Landfill have been coercive, using state and council police. These methods, as admitted to by members of the Health Department of the City Council, have failed. Coercion means power and power means the domination of man by man (Dugan, 2003). Therefore, people do not like coercion. They must understand why they are being removed from their means of subsistence. Consequently, the stand taken by the Council to engage waste pickers in a dialogue, sensitizing them on the dangers of waste picking, may have 
longer lasting effects than coercion. This is what Janse van Rensburg (1999) means when he says education plays a transformative role in societies. Similarly, Fien (1993) also explains that education is the world's greatest resource in bringing about preparedness for changes in social systems towards sustainable living.

At the second level, government policies and strategies need to be in tandem with creating sustainable enterprises and jobs. For example, the Government of Zambia had to revise the Sixth National Development Plan (called the R-SNDP) in order to incorporate emerging issues such as creation of a green economy and jobs that can help reinforce sustainable development efforts (Ministry of Finance). Of the three strategic focuses of the R-SNDP, two are important to this study, namely focus on inclusiveness and job creation. By inclusiveness is meant economic growth that is shared equitably among all stakeholders in the country by deliberately targeting deprived areas and people. Waste pickers, no doubt, are among deprived people and can benefit from these Government policies and strategies. By job creation is meant increasing gainful employment to reduce poverty levels. These focus directions are in synch with the International Labour Organization's key areas of intervention for job-rich green growth, which are listed as follows(Queye, 2013):

(a) Creating more jobs which will sustain the environment but also mainstream the youth into the job market with linkages to various sectors and youth development initiatives.

(b) Ensuring quality employment, that is, jobs created should meet decent work criteria and addressing issues specific to the informal sector. According ILO, jobs with the greatest development payoffs, inter alia, are those that protect the environment, foster trust and civic engagement, or reduce poverty. Such jobs have the following characteristics: adequate incomes for basic needs; reasonable level of economic security; freedom, basic rights, opportunities; and voice, self-esteem, self-fulfillment and dignity. These qualities are, in all intent and purpose, lacking in waste picking as a form of employment.

(c) Advancing social inclusion: This includes coming up with social protection policies, occupational changes, skills building and upgrading, retraining of workers.

Waste pickers are vulnerable people because of their status and the type of work they do and could profit from such government policies and strategies. It will give the waste pickers better jobs, social security, health and safety, and gender equality. The Zambia National Policy envisions to simultaneously protect the natural environment and support the Government's development priority to eradicate poverty and improve the quality of life of the people of Zambia (Ministry of Lands, Natural Resources, and Environmental Protection). The ILO calls this the 'Dual Challenge of the $21^{\text {st }}$ Century', which is depicted in Figure 7below:

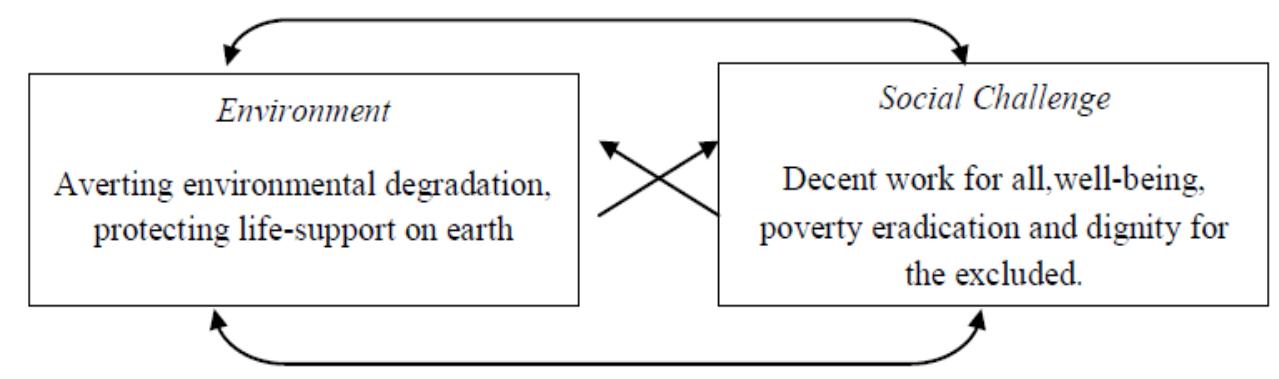

Figure7. The ILO's dual challenge of the $21^{\text {st }}$ Century

Source: Gueye (2013)

Some of the guiding principles of the national policy are sound resource utilisation, social justice, equitable resource allocation and care for the environment; and achieving environmental sustainability.

\section{Conclusions}

This study investigated waste picking at Chunga Landfill in Lusaka the capital city of Zambia. Like for many waste picking sites around the world, waste picking at Chunga was found to be associated with many problems, including socio-economic, occupational and environmental. In the light of these problems, the study makes two recommendations. Firstly, waste pickers need to be provided with 
sustainable employment alternatives. Such employment, as suggested by ILO (Gueye, 2013), has the following characteristics: adequate incomes for basic needs; reasonable level of economic security; freedom, basic rights, opportunities; and voice, self-esteem, self-fulfillment and dignity. Secondly, waste pickers need to have opportunities for entrepreneurship, skills, competencies and jobs. If empowered with capital and skills, waste pickers could run their own waste collecting enterprises or they could become sorters. This is called building skills for green jobs. For this to happen, waste pickers could be helped through creative microfinance and other small-scale investments (Iskandar, 2001).

\section{REFERENCES}

[1] Bartone, C. (1988). The Value in Wastes. Decade Watch, January 1988.

[2] Binion,E., \& Gutberlet, J. (2012). The effects of handling solid waste on the wellbeing of informal and organized recyclers: a review of the literature. International Journal of Occupational and Environmental Health, 18 (1): 43-52.

[3] Deutsch, K.(1963). The Nerves of Government: Models of Political communication and Control. New York: Free Press.

[4] Douglas, M. (1984). Purity and danger: An analysis of concepts of pollution and taboo. New York: Routledge and Kegan Paul.

[5] Dugan,M. A (2003). Coercive Power. Beyond Intractability, Available from: http://www. Beyond intractability.org/essay/threats, [Accessed on $12^{\text {th }}$ November, 2013].

[6] CIA (2013). CIA World Factbook. Available from: www.indexmundi.com/world/unemployment rate.html, [Accessed on28 ${ }^{\text {th }}$ January, 2014].

[7] Gowan, T. (2010). Hobos, Hustlers, and Backsliders: Homeless in San Francisco. Minneapolis: University of Minnesota Press.

[8] Gowan, T. (1997). American Untouchables: Homeless Scavengers in San Francisco's Underground Economy. International Journal of Sociology and Social Policy, 17 (3/4): 159.

[9] Gutberlet, J. (1997). Informal Recycling and Occupational Health in Santo André, Brazil, International Journal of Environmental Health Research, 18 (1): 1-15.

[10] GTZ (2010). The Economic Aspects of the Informal Sector in Solid Waste Management, German Technical Cooperation

[11] Huysman, M (1994), Waste-picking as a survival strategy for women in Indian cities, Environment and Urbanization, 6 (2):155-174.

[12] Medina, M. (2007). The World's Scavengers: Salvaging for Sustainable Consumption and Production. New York: Altamira Press.

[13] Melanie, S. (2008). Refusing to be cast aside: Waste pickers organising around the World. Cambridge, MA: WEIGO. Available from : http://www.otherworldsarepossible.org/ resources/ refusing-be-cast-aside-waste-ickers-organising-around-world [Accessed on $14^{\text {th }}$ May, 2017].

[14] Mulenga, I.M. (2015). English Language Teacher Education curriculum designing: A mixed methods analysis of the programme at the University of Zambia. Unpublished thesis for the degree of Doctor of Philosophy in Curriculum Studies, Lusaka: University of Zambia.

[15] Mweemba, L. (in press). Learning and sustainable development: A pathway to sustainability. In C.M. Namafe (ed.). Learning Sustainable Development in Zambia through Environmental Education.

[16] O'Donoghue, R. \& Janse Van Rensburg, U. (Eds.). (1995) Environments and methods. Howick: Share-Net.

[17] Parizeau, K. (2013). Formalization beckons: a baseline of informal recycling work in Buenos Aires, 2007-2011. Environment and Urbanization 25.

[18] SADC REEP (2002). SADC Regional Environmental Education Programme. Programme Document. Share-Net, Howick.

[19] Scheinberg, A. and J. Anschütz (2007). Slim pickin's: Supporting waste pickers in the ecological modernisation of urban waste management systems. International Journal of Technology Management and Sustainable Development, 5 (3): 257-27. 
[20] Srinivas, H. (n.d.). Solid Waste Management: Glossary. The Global Development Research Center. [Accessed on $13^{\text {th }}$ November, 2013].

[21] US Department for Housing and Urban Development (2008). Accessing Mainstream Employment and Income Support Programmes, Office of Community Planning and Development, HUD's Homeless Assistance Programmes.

[22] Velis, C. (2012). An analytical framework and tool (InteRa) for integrating the informal recycling sector in waste and resource management systems in developing countries. Waste Management and Research Supplement, 30 (9): 43-66.

[23] Vidanaarachchi, C.K., Yuen, S.T.S. and Pilapitiya, S. (2006). Municipal solid waste management in the Southern Province of Sri Lanka: Problems, issues and challenges. Journal of Waste Management 26: 920-930.

[24] WHO (2005). Children's health and the environment - a global perspective. A resource manual for the health sector. The World Health Organisation.

[25] WIEGO (2014). Waste Picking, Women in Informal Employment: Available from: http://wiego.org/ informal-economy/occupational-groups/waste-pickers [Accessed on 27th January, 2014].

[26] Wilson, D.C., Velis, C., and Cheeseman, C. (2005). Role of informal sector in recycling in waste management in developing countries. London: Department of Civil and Environmental Engineering, Centre for Environmental Control and Waste Management.

[27] World Bank (2014). World Development Indicators: Unemployment. Available from:http://data. worldbank.org/indicator/SL.UEM.TOTL.ZS[Accessed on $26^{\text {th }}$ January, 2014].

\section{AUTHORS' BibLIOGRAPHY}

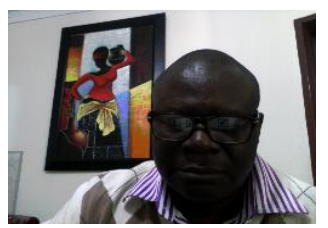

Bernard Chileshe, is a lecturer and $\mathrm{PhD}$ student of environmental education at the University of Zambia. His main research interest is in waste management behaviour. His current research projects focus on environmentally significant behaviour, human behaviour patterns in relation to environmental quality, quality of life, and sustainable development and indigenous knowledge systems in waste management.

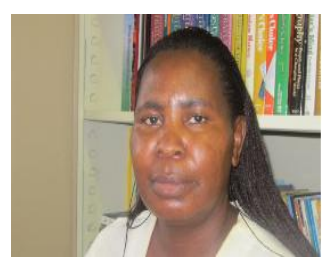

Mirriam Sampa Moonga, is a female lecturer and researcher, an environmental educator at the University of Zambia (UNZA) in the faculty of Education, Department of Language and Social Sciences Education. She holds a B.A. in Education and M.A in Environmental Education both from UNZA. Mirriam is currently pursuing her $\mathrm{PhD}$ in Environmental Education at the University of Zambia. She is very passionate about ESD activities. Especially networks and has attended, participated and presented several papers at local, regional and international training, workshops and conferences on EE/ESD. Her research interest is in ESD. 